\title{
Pembatasan Usia Perkawinan (Tinjauan Undang-undang dan Maqashid asy-Syari'ah)
}

\author{
Elkhairati \\ Sekolah Tinggi Agama Islam Negeri (STAIN) Curup \\ Email: elkhairati9@gmail.com
}

\begin{abstract}
This article aims to review the Law and Maqashidasy-Syari'ah regarding the age limit of marriage. The literature of Islamic Law (figh) does not explicitly specify the minimum age limit for prospective marriages. Over the course of time, the law privides a minimum age of mariage. There is a clear conflict between the fiqh and the laws. According to the ushuliyin (Islamic law experts)view, in order to produce a law or a fatwa law, a mujtahid (legal exciter) should pay attention to maqashidsyari'ah (lawmaking purposes). Because the shari'ah is revealed to realize the benefit of mankind, including the marriage problem. The main problem of this research is to investigate the minimum age restriction of marriage according to the law and how to view the maqashidasy-shari'ah against the provisions of the law. This research used library method. Based on the analysis, it can be concluded that the limitation of the minimum age of marriage in the law is intended for the benefit of the family and the ability to achieve the purpose of marriage. Thus, it can be said that it is in accordance with the application of the maqashidasy-shari'ah, that is to preserve human benefit at the level of an-nasal hifdz (nurturing offspring).
\end{abstract}

Keywords: Age of Marriage, Family Law, Maqashid asy-Syari'ah

\begin{abstract}
Abstrak
Artikel ini bertujuan untuk meihat tinjauan Undang-undang dan Maqashid asy-Syari'ah mengenai batas usia perkawinan. Literatur Hukum Islam (fiqh), tidak menetapkan secara tegas tentang batas minimal usia calon pengantin. Seiring perkembangan zaman UU memberikan batas minimal usia perkawinan. Jelas terjadi benturan antara fiqh dan UU. Melihat hal itu dari kacamata ushuliyin(pakar hukum Islam), bahwa untuk melahirkan sebuah undang-undang atau fatwa hukum, maka seorang mujtabid (penggali hukum) harus memperhatikan maqashid syariah (tujuan pembuatan hukum). Karena memang syariah diturunkan untuk mengujudkan kemaslahatan umat manusia, termasuk juga dalam persoalan pernikahan. Masalah pokok penelitian ini adalah melihat bagaimana bentuk pembatasan usia minimal perkawinan menurut ketentuan undang-undang
\end{abstract}

Al Istinbath : Jurnal Hukum Islam vol. 3, no. 1, 2018

STAIN Curup-Bengkulu | p-issn: 2548-3374; e-issn: 2548-3382

Available online at : http://journal.staincurup.ac.id/index.php/alistinbath 
dan kemudian bagaimana pula pandangan maqashid asy-syariah terhadap ketentuan Undang-undang tersebut. Penelitian menggunakan metode kepustakaan. Berdasarkan analisis yang dilakukan dapat dikatakan bahwa pembatasan umur minimal perkawinan dalam Undang-undang tersebut dimaksudkan untuk kemaslahatan keluarga dan mampu meraih tujuan perkawinan. Dengan demikian dapat dikatakan sesuai dengan penerapan maqashid asy-syari'ah, yaitu memelihara kemaslahatan manusia dalam tataran bifdz an-nasal (memelihara keturunan).

Kata kunci: Usia Perkawinan, Undang-undang Hukum Keluarga, Maqashid asy-Syari'ah

\section{Pendahuluan}

Sekitar tahuan 2008 lalu, Indonesia dihebohkan dengan pemberitaan dari Semarang-Jawa Tengah, seorang pengusaha sekaligus pemilik pondok pesantren bernama Pujiono Cahyo Widianto alias Syeh Puji-saat itu berusia 43 tahun-, menikahi seorang anak gadis berusia 12 tahun dan baru menyelesaikan sekolah dasar (SD), bernama Lutfina Ulfa. Peristiwa tersebut membuat banyak orang mengeluarkan statement termasuk Menteri Agama, KOMNAS Perlindungan Anak dan para pemerhati masalah anak. Pro-kontra dari berbagai sudut pandang bermunculan, baik sudut pandang agama Islam, Undang-undang Perlindungan Anak, Undang-undang Perkawinan hingga Konvensi PBB tentang Hak Anak menghiasi siaran berita dan dialog di media cetak dan elektronik.

Kampanye penolakan pernikahan di usia dini yang dilakukan oleh PKPA melalui berbagai media sosialisasi sering mendapatkan pertanyaan mendasar mengenai batasan minimal usia perkawinan. Bukan hal mudah menjawab pertanyaan sederhana yang disampaikan masyarakat. Meskipun Undang-Undang nomor 23 tahun 2002 tentang Perlindungan Anak menyatakan secara tegas,"Anak adalah seseorang yang belum berusia 18 (delapan belas) tahun, termasuk anak yang masih dalam kandungan". (Pasal 1) dan pada pasal 26 ayat 1 poin c disebutkan, keluarga dan orang tua berkewajiban untuk mencegah terjadinya perkawinan di usia anak-anak. Secara jelas undang-undang ini mengatakan, tidak seharusnya pernikahan dilakukan terhadap mereka yang usianya masih di bawah 18 tahun. ${ }^{1}$ Namun tidak semudah itu PKPA dapat menjawabnya, karena UU No.1 tahun 1974 tentang perkawinan memberikan batasan yang berbeda dan tidak konsisten terhadap batas minimal usia perkawinan. Dalam pasal 6 terpahami bahwa calon pasangan suami isteri adalah 21 tahun. Sedangkan dalam pasal 7 ayat (1) menjelaskan usia calon suami 19 sedangkan calon isteri 16 tahun. Pasal 7 UU Perkawinan inilah yang diikuti oleh

${ }^{1}$ BCZ Online/Kamis, 30 Oktober 2008 dalam http://www.waspada.co.id/opini/ pernikahan-dini-dan-tuntutan.html.(diakses tgl 13 Januari 2010) 
Kompilasi Hukum Islam (KHI) tentang batas usia calon mempelai, tepatnya pasal 15.

Di tengah kontroversi hukum di Indonesia mengenai batas minimun usia perkawinan, pernikahan di usia dini juga terjadi karena penafsiran terhadap ajaran agama. Pernyataan Syekh Puji di berbagai media massa yang mengatakan bahwa pernikahannya dengan Ulfa, merupakan teladan dari Nabi Muhammad SAW yang menikahi Aisyah ketika itu berusia 9 tahun.

Sementara itu dalam literatur Hukum Islam (fiqh), pada dasarnya ketentuan tentang batas umur minimal perkawinan tidak ditentukan secara tegas. Mayoritas pakar hukum Islam melegalkan pernikahan dini.

Disamping itu, sejarah telah mencatat bahwa Aisyah dinikahi Baginda Nabi SAW dalam usia sangat muda. Begitu pula pernikahan dini merupakan hal yang lumrah di kalangan sahabat. Bahkan sebagian ulama menyatakan pembolehan nikah dibawah umur sudah menjadi konsensus pakar hukum Islam.

Nampaknya antara ajaran agama dan negara terjadi perselisihan dalam memaknai pernikahan dini. Pernikahan yang dilakukan melewati batas minimnal Undang-undang Perkawinan, secara hukum kenegaraan tidak sah. Istilah pernikahan dini menurut negara dibatasi dengan umur. Sementara dalam kaca mata agama, pernikahan dini ialah pernikahan yang dilakukan oleh orang yang belum baligh.

Pemerintah melarang pernikahan usia dini adalah dengan pelbagai pertimbangan, sedangkan agama membolehkan pernikahan dini juga dengan mempertimbangkan mashlahah. Sebuah permasalahan yang cukup dilematis.

Melihat hal itu dari kacamata ushuliyin (pakar hukum Islam), menegaskan bahwa untuk melahirkan sebuah undang-undang atau fatwa hukum, maka seorang mujtahid (penggali hukum) harus memperhatikan maqashid syari'ah (tujuan pembuatan hukum). Karena memang syariah diturunkan untuk mengujudkan kemaslahatan umat manusia, termasuk juga dalam persoalan pernikahan.

Oleh karena itu, kebijakan pemerintah dengan mengeluarkan Undangundang yang melarang pernikahan usia dini atau dengan kata lain membatasi usia minimal perkawinan haruslah sesuai dengan maqasid asy-syariah. Jangan sampai penetapan undang-undang mengalahkan ketentuan agama. Padahal diketahui bahwa manusia mempunyai kemampuan yang terbatas untuk bisa menerawang kedepan guna menentukan apa yang terbaik bagi diri mereka. Jangan hanya karena tuntutan emansipasi wanita dari beberapa organisasi komnas perempuan dan atau hanya karena mengatas namakan komnas perlinduingan anak, hukum harus menginjak norma agama yang sudah ditetapkan oleh sang pembuat hukum Allah SWT malalui Nabi SAW, karena belum tentu anak yang melakukan 
pernikahan dibawah umur akan mendapatkan kengerian sebagaimana dibayangkan banyak orang.

Berpijak dari latar belakang masalah di atas, masalah utama yang hendak dijawab dalam penelitian ini adalah bagaimana bentuk pembatasan usia minimal perkawinan menurut ketentuan Undang-undang, dan bagaimana pula pandangan maqashid asy-syariabterhadap pembatasan usia minimal perkawinan dalam Undang-undang tersebut? Untuk menjawab pertanyaan tersebut dilakukan penelitian kepustakaan (libary reseach).

\section{Pembahasan}

\section{Undang-Undang Perkawinan No. 1 Tahun 1974}

Dalam pasal 1 UU Perkawinan No. 1 Tahun 1974 dinyatakan: Perkawinan adalah ikatan lahir batin antara seorang pria dan seorang wanita sebagai suami istri dengan tujuan membentuk keluarga atau rumah tangga yang bahagia dan kekal berdasarkan Ketuhanan Yang Maha Esa. ${ }^{2}$

Ikatan lahir adalah hubungan formal yang dapat dilihat karena dibentuk menurut Undang-undang, hubungan mana mengikat kedua pihak dan pihak lain dalam masyarakat. Ikatan batin adalah hubungan yang tidak formal yang dibentuk dengan kemauan bersama yang sungguh-sungguh, dan hanya mengikat kedua pihak saja. Untuk mencapai tujuan mulia itu, UU memberikan persyaratan yang harus dipenuhi. Dalam pasal 6 ayat (1) Perkawinan didasarkan atas persetujuan kedua calon mempelai. ${ }^{3}$ Artinya, kedua mempelai sepakat untuk melangsungkan perkawinan, tanpa ada paksaan dari pihak manapun juga. Hal ini sesuai dengan hak asasi manusia atas perkawinan, dan sesuai juga dengan tujuan perkawinan yaitu membentuk keluarga yang bahagia dan kekal.

Barangkali terinspirasi dengan tujuan perkawinan membentuk keluarga yang bahagia dan kekal itu, maka UU memberikan persyaratan yang harus dipenuhi; diantaranya batasan umur minimal calon mempelai adalah 21 tahun, tetapi belum ditetapkan secara tegas bagi siapa umur 21 tahun tersebut. Kemudian pada pasal 7 ayat (1) baru dipastikan rincian batas usia yang diizinkan dalam suatu perkawinan menurut UU yaitu, jika pihak pria sudah mencapai umur 19 (sembilan belas) tahun, dan pihak wanita sudah mencapai umur 16 (enam belas) tahun. ${ }^{4}$ Nampaknya pada pasal 7 ayat (1) ini, terjadi pengurangan, yaitu; untuk laki-laki minimal 19 tahun dan perempuan minimal umur 16 tahun.

Meskipun UU telah menggariskan batasan usia minimal perkawinan,

${ }^{2} \mathrm{http}: / /$ www.asiamaya.com/konsultasi, (diakses tanggal 23 Maret 2015)

3http://www.Pustaka: yayasan Peduli Anak Negeri (YPAN), [selanjutnya disebut, YPAN] (diakses tanggal 5 Oktober 2015)

${ }^{4}$ Ibid. 
namun dalam pasal 6 ayat (2) di atas, juga disebutkan; jika kedua pasangan belum mencapai 21 tahun harus ada izin dari kedua orang tua untuk melangsungkan pernikahan. Ketentuan dispensasi ini juga diperkuat dengan pasal 7 ayat (2); Dalam hal penyimpangan dalam ayat (1) pasal ini dapat minta dispensasi kepada Pengadilan atau pejabat lain yang diminta oleh kedua orang tua pihak pria atau pihak wanita. ${ }^{5}$ Selanjutnya, mekanisme memperoleh dispensasi tersebut diatur dalam pasal 6:

Menurut ayat (3) Dalam hal salah seorang dari kedua orang tua telah meninggal dunia atau dalam keadaan tidak mampu menyatakan kehendaknya, maka ijin yang dimaksudkan dalam ayat (2) cukup diperoleh dari orang tua yang masih hidup atau orang tua yang mampu menyatakan kehendaknya. Menurut ayat (4) Dalam hal kedua orang tua telah meninggal dunia atau dalam keadaan tidak mampu untuk menyatakan kehendaknya, maka ijinnya diperoleh dari wali, orang yang memelihara atau keluarga yang mempunyai hubungan darah dalam garis keturunan lurus ke atas, selama mereka masih hidup atau mampu menyatakan kehendaknya. Menurut ayat (5) Dalam hal ada perbedaan pendapat pendapat antara orang-orang yang disebut dalam ayat (2), (3), (4) pasal ini, salah seorang atau lebih diantara mereka itu tidak menyatakan pendapatnya, maka Pengadilan dalam daerah hukum tempat tinggal orang yang akan melangsungkan perkawinan atas permintaan orang tersebut dapat memberi izin setelah lebih dahulu mendengar orang-orang tersebut dalam ayat (2), (3), (4) pasal ini. Menurut ayat (6) Ketentuan menurut ayat (1) sampai dengan ayat (5) pasal ini, berlaku sepanjang hukum masing-masing agama dan kepercayaan dari yang bersangkutan tidak menentukan lain.6

Dari paparan di atas terlihat bahwa UU Perkawinan No 1 Tahun 1974 memang telah menetapkan batasan usia yang diizinkan untuk melangsungkan perkawinan, namun ketentuan itu tidaklah kaku karena Undang-undang juga memberikan jalan keluar bagi pasangan dibawah umur untuk mengadakan ikatan perkawinan. Kelonggaran itu dapat diperoleh dengan adanya izin dari orang tua, wali atau keluarga terdekat. Jika kesepakatan perizinan belum juga didapat, maka bisa mengajukan permohonan dispensasi kepada lembaga yang telah diberi wewenangan untuk itu, seperti kepada Pengadilan atau pejabat lain yang ditunjuk oleh kedua orang tua pihak pria maupun pihak wanita.

Tetapi bagi para pihak yang tidak mengindahkan ketentuan tersebut, maka pasal 20 dan 21 UU No. 1 tahun 1974 cukup tegas dalam masalah ini. Disebutkan bahwa pegawai pencatat pernikahan tidak diperbolehkan melangsungkan atau membantu melangsungkan perkawinan bila ia mengetahui 
antara lain adanya pelanggaran dari ketentuan batas umur minimum pernikahan. ${ }^{7}$

\section{Menurut Hukum Perdata}

Menurut ketentuan Kitab Undang-undang Hukum Perdata (KUHP) dalam pasal 29 menentukan:

Setiap jejaka yang belum mencapai umur genap delapan belas tahun, seperti pun seorang gadis yang belum mencapai umur genap lima belas tahun, tak diperbolehkan mengikat dirinya dalam perkawinan. Sementara itu, dalam hal adanya alasan-alasan yang penting, Presiden berkuasa meniadakan larangan ini dengan memberikan dispensasi. ${ }^{8}$

Berpijak pada ketentuan pasal 29 ini, dapat ditarik pemahaman bahwa KUHP Perdata membatasasi usia pasangan suami isteri, yaitu 18 tahun bagi laki-laki dan 15 tahun bagi perempuan. Ini jelas berbeda dengan ketentuan UU Perkawinan No 1 Tahun 1974 di atas yang memberikan batasan umur 19 tahun untuk laki-laki dan 16 tahun bagi perempuan. Pasal 29 ini juga membenarkan perkawinan di bawah umur jika ada alasan-alasan penting, dengan cara minta dispensasi dari presiden.

Sementara itu, dalam pasal 35 dijelaskan ketentuan perkawinan bagi pasangan di bawah umur. Selengkapnya berbunyi:

Untuk mengikat diri dalam perkawinan, anak-anak wakin yang belum dewasa harus memperoleh izin dari kedua orang tua mereka. Jika hanya satu diantara mereka memberikan izinnya, dan orang tua yang lain dipecat dari kekuasaan orang tua atau perwalian atas diri si anak, maka Pengadilan Negeri yang mana dalam daerah hukumnya, anak itu mempunyai tempat tinggalnya, atas permintaan anak, berkuasa memberikan izin untuk kawin, setelah mendengar atau memanggil dengan sah akan mereka yang izinnya diperlukan, dan akan para keluarga sedarah dan semenda. Jika satu orang tua telah meninggal dunia, atau berada dalam keadaan tak mampu menyatakan kehendaknya, maka izin cukup diperoleh dari orang tua yang lain. ${ }^{9}$

Anak-anak yang belum dewasa memerlukan juga izin dari wali mereka, bila yang melakukan perwalian adalah orang lain daripada bapak atau ibu mereka; bila izin itu diperbolehkan untuk kawin dengan salah satu dari keluarga sedarah dalam garis lurus, diperlukan izin dari wali pengawas (pasal 36). ${ }^{10}$ Bila bapak atau ibu telah meninggal atau berada dalam keadaan tidak mampu menyatakan kehendak mereka, maka mereka masing-masing harus

${ }^{7}$ Ibid.

${ }^{8}$ Soesilo, Pramuji R, Kitab Undang-undang Hukum Perdata Burgerlijk Wetboek, (Jakarta: Wippress, 2007), h. 8.

Ibid., h. 9

${ }^{10}$ Ibid. 
diganti oleh orang tua mereka, sejauh mereka masih hidup dan tidak dalam keadaan yang sama (pasal 37). ${ }^{11}$ Anak luar kawin yang diakui sah, selama masih dibawah umur, tidak boleh melakukan perkawinan tanpa izin bapak dan ibu yang mengakuinya, sejauh kedua-duanya atau salah seorang masih hidup dan tidak berada dalam keadaan tak mampu menyatakan kehendak mereka. Bila semasa hidup bapak atau ibu yang mengakuinya, orang lain yang melakukan perwalian atas anak itu, maka harus pula diperoleh izin dari wali itu atau dari wali pengawas bila izin itu diperlukan untuk perkawinan dengan wali itu sendiri atau dengan salah seorang dari keluarga sedarah dalam garis lurus (pasal 39). ${ }^{12}$ Anak yang tidak sah yang tidak diakui, tidak boleh melakukan perkawinan tanpa izin wali atau wali pengawas, selama ia masih dibawah umur. Bila kedua-duanya, atau salah seorang, menolak untuk memberikan izin, atau untuk menyatakan pendirian, Pengadilan Negeri di daerah hukum tempat tinggal anak yang masih dibawah umur itu, atas permohonannya, berkuasa untuk memberikan izin untuk itu, setelah mendengar atau memanggil dengan sah wali atau wali pengawas si anak (pasal 40). ${ }^{13}$

Prosedur yang telah digariskan KUHP Perdata tersebut, agaknya bertujuan untuk melindungi anak di bawah umur dari tindak kejahatan kesusilaan yang ditimbulkan dari akibat perkawinan dibawah umur, sehingga dalam pasal 288 KUHP Pidana telah menyebutkan bahwa:

Barang siapa dalam perkawinan bersetubuh dengan seorang wanita yang diketahuinya atau sepatutnya harus diduganya bahwa yang bersangkutan belum waktunya untuk dikawin, apabila mengakibatkan luka-luka diancam dengan pidana penjara paling lama empat tahun, Jika mengakibatkan lukaluka berat diancam pidana penjara paling lama delapan tahun dan jika mengakibatkan mati diancam pidana penjara paling lama dua belas tahun. ${ }^{14}$

\section{Menurut Kompilasi Hukum}

KHI, yang disebarluaskan melalui Inpres No. 1 Tahun 1991 memuat perihal yang kurang lebih sama. Pada pasal 15, KHI menyebutkan bahwa batas usia perkawinan sama seperti pasal 7 UU No. 1 Tahun 1974, namun dengan tambahan alasan: untuk kemaslahatan keluarga dan rumah tangga. Selengkapnya berbunyi:

(1) Untuk kemaslahatan keluarga dan rumah tangga, perkawinan hanya boleh dilakukan calon mempelai yang telah mencapai umur yang

${ }^{11}$ Ibid.

${ }^{12}$ Ibid., h. 10.

${ }^{13}$ Ibid., h. 11

${ }^{14}$ Trinity, KitabUndang-undang Hukum Pidana KUHP, ([tt.]: Trinity Optima Media, 2007), Cet ke-1, h. 90. 
ditetapkan dalam pasal 7 Undang-undang No.1 tahun 1974 yakni calon suami sekurang-kurangnya berumur 19 tahun dan calon isteri sekurangkurangnya berumur 16 tahun

(2) Bagi calon mempelai yang belum mencapai umur 21 tahun harus mendapati izin sebagaimana yang diatur dalam pasal 6 ayat (2),(3),(4) dan (5) UU No.1 Tahun 1974. ${ }^{15}$

Pasal ini, ternyata secara eksplisit KHI tidak mencantumkan secara jelas larangan untuk menikah di bawah umur. Penyimpangan terhadapnya dapat dimungkinkan dengan adanya izin dari pengadilan atau pejabat yang berkompeten.

Namun demikian perkawinan di bawah umur dapat dicegah dan dibatalkan. Pasal $60 \mathrm{KHI}$ menyebutkan pencegahan perkawinan dapat dilakukan bila calon suami atau calon isteri tidak memenuhi syarat-syarat untuk melangsungkan perkawinan menurut hukum Islam dan peraturan perundang-undangan. ${ }^{16}$ Pihak yang dapat mencegah perkawinan adalah para keluarga dalam garis keturunan lurus ke atas dan ke bawah, saudara, wali nikah, wali pengampu dari salah seorang calon mempelai, suami atau isteri yang masih terikat dalam perkawinan dengan salah seorang calon isteri atau calon suami, serta pejabat yang ditunjuk untuk mengawasi perkawinan (pasal 62, 63, dan $64 \mathrm{KHI}){ }^{17}$

KHI juga menyebutkan perkawinan dapat dibatalkan antara lain bila melanggar batas umur perkawinan sebagaimana ditetapkan dalam Pasal 7 UU No. 1 tahun 1974. Pasal 71 menyebutkan bahwa para pihak yang dapat mengajukan permohonan pembatalan perkawinan. ${ }^{18}$ Mereka yang berhak mengajukan permohonan itu adalah: (1) para keluarga dalam garis keturunan lurus ke atas dan ke bawah dari suami atau isteri; (2) suami atau isteri; (3) pejabat yang berwenang mengawasi pelaksanaan perkawinan menurut Undang-Undang; (4) para pihak berkepentingan yang mengetahui adanya cacat dalam rukun dan syarat perkawinan menurut hukum Islam dan peraturan perundangan-undangan (pasal 73). ${ }^{19}$

\section{Instrumen HAM}

Instrumen Hak Asasi Manusia-apakah yang bersifat internasional (international buman rights law) ataupun yang sudah diratifikasi oleh

${ }^{15}$ http://www. Disalin dari "Kompilasi Hukum Islam di Indonesia", Direktorat Pembinaan Peradilan Agama Islam Ditjen Pembinaan Kelembagaan Islam Departemen Agama, 2001, (diakses tanggal 25 Juni 2002)

${ }^{16}$ Ibid.

${ }^{17}$ Ibid.

${ }^{18} \mathrm{Ibid}$.

${ }^{19}$ Ibid. 
Pemerintah RI-tidak menyebutkan secara eksplisit tentang batas usia perkawinan. Konvensi Hak Anak (Convention on the Rights of the Child 1990 yang telah diratifikasi melalui Keppres No. 36 Tahun 1990) tidak menyebutkan usia minimal pernikahan selain menyebutkan bahwa yang disebut anak adalah mereka yang berusia di bawah 18 tahun. Juga setiap negara peserta konvensi diwajibkan melindungi dan menghadirkan legislasi yang ramah anak, melindungi anak dan dalam kerangka kepentingan terbaik bagi anak (the best interest of the child). ${ }^{20}$

Konvensi tentang Kesepakatan untuk Menikah, Umur Minimum Menikah dan Pencatatan Pernikahan (Convention on Consent to Marriage, Minimum Age for Marriage and Registration of Marriages) 1964 menyebutkan bahwa negara peserta konvensi ini akan mengupayakan labirnya legislasi untuk mengatur permasalahan umur minimum untuk menikah dan bahwasanya pernikahan yang dilakukan di luar umur minimum yang ditetapkan adalah tidak berkekuatan hukum, terkecuali otoritas yang berwenang menetapkan dispensasi tertentu dengan alasan yang wajar dengan mengedepankan kepentingan pasangan yang akan menikah. ${ }^{21}$

Indonesia belum menjadi negara pihak dari Konvensi 1964 tersebut, namun telah menetapkan usia minimum pernikahan melalui UU No. 1 Tahun 1974 tentang Perkawinan, alias sepuluh tahun setelah Konvensi tersebut lahir.

UU No. 23 Tahun 2002 tentang Perlindungan Anak-sebagai instrumen HAM-juga tidak menyebutkan secara eksplisit tentang usia minimum menikah selain menegaskan bahwa anak adalah mereka yang berusia di bawah 18 tahun. Disebutkan pula, penyelenggaraan perlindungan anak berasaskan Pancasila dan berlandaskan Undang-Undang Dasar Negara Republik Indonesia Tahun 1945 serta prinsip-prinsip dasar Konvensi HakHak Anak meliputi: a. non diskriminasi; b. kepentingan yang terbaik bagi anak; c. hak untuk hidup, kelangsungan hidup, dan perkembangan; dan d. penghargaan terhadap pendapat anak. ${ }^{22}$

Perlindungan anak bertujuan untuk menjamin terpenuhinya hak-hak anak agar dapat hidup, tumbuh, berkembang, dan berpartisipasi secara optimal sesuai dengan harkat dan martabat kemanusiaan, serta mendapat perlindungan dari kekerasan dan diskriminasi, demi terwujudnya anak Indonesia yang berkualitas, berakhlak mulia, dan sejahtera. Terkait pernikahan di bawah umur.

Dalam Undang-undang nomor 23 tahun 2002 tentang Perlindungan Anak menyatakan secara tegas; anak adalah seseorang yang belum berusia

${ }^{20} \mathrm{http://www.asiamaya.com/konsultasi,} \mathrm{(diakses} \mathrm{tanggal} 25$ Juni 2015)

${ }^{21}$ Ibid.

22Ibid. 
18 (delapan belas) tahun, termasuk anak yang masih dalam kandungan. Pasal 1 dan pada pasal 26 ayat (1) poin c disebutkan, keluarga dan orang tua berkewajiban untuk mencegah terjadinya perkawinan di usia anak-anak. Secara jelas undang-undang ini mengatakan, tidak seharusnya pernikahan dilakukan terhadap mereka yang usianya masih di bawah 18 tahun. ${ }^{23}$ Namun tidak semudah itu PKPA dapat menjawabnya, karena UU No.1 tahun 1974 tentang perkawinan memberikan batasan yang berbeda dan tidak konsisten terhadap batas minimal usia perkawinan.

\section{Menurut Hukum Keluarga di Dunia Muslim}

Dalam UU Turki umur minimal seseorang yang hendak nikah adalah 18 tahun bagi laki-laki 17 tahun bagi perempuan. Dalam kasus-kasus tertentu pengadilan dapat mengijinkan pada usia 15 tahun bagi laki-laki dan 14 tahun bagi perempuan setelah mendapat ijin orang tua atau wali. ${ }^{24} \mathrm{Dalam}$ fiqh Hanafi yang menjadi rujukan UU di Turki, tidak secara kongkrit menyebutkan tentang batasan umur pernikahan. Hanya secara tegas disebutkan bahwa salah satu syarat pernikahan adalah baligh beraka, sebagaimana juga keduanya menjadi syarat umum bagi operasinalisasi seluruh tindakan yang bernuansa hukum. Karena itu baligh hanyalah syarat bagi kelangsungan suatu tindakan hukum bukan merupakan syarat keabsahan pernikahan. ${ }^{25}$

Di Iran, menurut Homaidi Hamid,UU mengatur bahwa usia minimum boleh melaksanakan perkawinan bagi pria 18 tahun dan 15 tahun untuk wanita. Bagi seseorang yang mengawinkan orang yang masih di bawah usia minimun nikah dapat dipenjara antara 6 bulan hingga 2 tahun. Jika seorang anak perempuan dikawinkan di bawah usia 13 tahun, maka yang mengawinkannya dapat dipenjara selama 2 hingga 3 tahun. Di samping itu bagi orang yang melanggar ketentuan ini dapat dikenakan denda 2-20 riyal. ${ }^{26}$

Usia minimun boleh malaksanakan perkawinan tersebut berbeda deangan pandangan mazhab Ja'fari yang mengatakan bahwa seseorang telah dipandang dewasa dan dapat melangsungkan perkawinan jika berumur 15 tahun bagi laki-laki dan 9 tahun bagi wanita. Mazhab ini juga memandang bahwa seorang wali boleh mengawinkan anak yang masih di bawah

${ }^{23}$ Ibid.

${ }^{24}$ Muhammad Amin ash-Shahir bin Ibn Ibidin, Hasyiyah Radd al-Mubtar, (Bairut: Dar alFikr, [t.th]), Jilid 2, h. 599.

${ }^{25} \mathrm{Ala}$ ad-Din Abu Bakr bin Mas'ud al-Kasani al-Hanafi, Bada'i as-Sana'i fi Tartib ashShara'i, (Bairut: al-Makhtabah al-'Ilmiyyah, [t.th]), Jilid 2, h. 232.

${ }^{26}$ M. Atho Mudzhar dan Khoiruddin Nasution (ed), Hukum Keluarga di Dunia Islam Modern; Studi Perbadingan dan Keberanjakan UU Modern dari Kitab-kitab Fikih, (Jakarta: Ciputat Press, 2003), h, 59. 
umur. ${ }^{27}$ Dengan demikian, ancaman hukuman bagi wali yang mengawinkan anak di bawah umur merupakan pembaharuan hukum keluarga Iran yang bersifat administratif.

Di Yaman Selatan menurut Saptoni, juga ditetapkan adanya pembatasan usia nikah, yaitu 18 tahun untuk laki-laki dan 16 tahun bagi wanita. Tetapi batasan ini tidak terkait dengan keabsahan akad nikah, hanya merupakan sesuatu yang perlu diperhatikan. Peraturan ini hanya bersifat anjuran, lantaran ketetapan ini hanya berasarkan kemaslahatan dan tidak banyak kepentingan negara untuk ikut mengaturnya. Bila dikaitkan dengan figh klasik, hal ini tentu tidak banyak berubah, sebagaimana ungkapan Imam asy-Syafi'i yang mengatakan bahwa saya lebih senang jika seorang ayah tidak menikahkan anak perempuannya sebelum baligh. ${ }^{28}$ Sedangkan di Syiria ditetapkan usia minimal untuk melangsungkan pernikahan adalah 18 tahun bagi laki-laki dan 17 tahun bagi perempuan. ${ }^{29}$

Hukum Keluarga Islam di Republik Tunisia menurut Zudi Rahmanto, diberikan batasan usia minimal melangsungkan pernikahan adalah 20 tahun bagi laki-laki dan perempuan. Ketentuan ini merupakan perubahan dari isi pasal 5 UU 1956, yang memberikan batasan 20 tahun bagi laki-laki dan 17 tahun untuk perempuan. Namun terhadap pasangan yang belum mencapai ketentuan umur di atas, harus mendapat izin khusus dari pengadilan. ${ }^{30}$

Hukum keluarga di Maroko menurut Atun Wardatun, menetapkan usia boleh untuk melangsungkan pernikahan adalah 18 tahun untuk pria dan 15 tahun untuk wanita. Namun demikian disyaratkan izin wali jika perkawinan dilakukan oleh pihak-pihak di bawah umur 21 tahun sebagai batas umur kedewasaan. ${ }^{31}$

Menurut Fatahuddin Aziz Siregar, di Aljazair dalam hukum keluarga 1984 pasal 7 secara jelas ditegaskan bahwa usia calon mempelai laki-laki 21 tahun dan calaon mempelai perempuan 18 tahun. Usian ini cukup tinggi di bandingkan dengan usia nikah yang terdapat dalam hukum keluarga di negara-negara Islam lain. Tercatat hanya Banglades yang menyamai batas minimun usia nikah ini. ${ }^{32}$

Menurut Ahmad Junaidi, dalam hukum sipil 1977 di Afganistan ditetapkan bahwa kompetensi untuk menikah adalah ketika sudah mencapai umur 18 tahun untuk laki-laki dan 17 tahun untuk wanita. Wanita yang

${ }^{27}$ Muhammad Jawad Mughniyah, Figh Lima Mąhab, penerjemah Masykur AB, Jakarta: Lentera, 1999), Cet ke-4, h. 316-318.

${ }^{28} \mathrm{M}$. Atho Mudzhar dan Khoiruddin Nasution (ed), Op. cit., h, 73-74.

${ }^{29} \mathrm{Ibid}$.

${ }^{30}$ Ibid., h, 87.

${ }^{31}$ Ibid., h, 109.

${ }^{32}$ Ibid., h, 125. 
belim mencapai umur ini hanya dapat dinikahkan oleh ayahnya atau qadi setelah mendapat ijin dari pengadilan. Pada tahun 1978 Majelis Revolusioner menerbitkan keputusan nomor 7, bahwa perkawinan di bawah 18 bagi laki-laki dan 16 bagi perempuan adalah terlarang, dan pealnggar dapat dikenakan penjara 6 bulan sampai 3 tahun. ${ }^{33}$ Di Somalia, menurut Habib, ditetapkan umur minimal 18 tahun bagi pria dan 16 tahun bagi wanita untuk dapat melangsungkan perkawinan. Hanya jasa dalam kondisi tertentu pihak pengadilan dapat memberikan ijin nikah bagi basangan yang belum cukup umur. ${ }^{34}$

\section{Pandangan Maqashid asy-Syari'ah terhadap Pembatasan Usia Perkawinan.}

Ushuliyin (pakar hukum Islam) menegaskan, bahwa untuk melahirkan sebuah undang-undang atau fatwa hukum, maka seorang mujtahid (penggali hukum) harus memperhatikan maqashid syari'ah (tujuan pembuatan hukum). Karena memang syari'ah diturunkan untuk mengujudkan kemaslahatan umat manusia, termasuk juga dalam persoalan pernikahan.

Oleh karena itu, kebijakan pemerintah dengan mengeluarkan Undangundang yang melarang pernikahan usia dini atau dengan kata lain membatasi usia minimal perkawinan haruslah sesuai dengan maqasid asy-syariah. Jangan sampai penetapan undang-undang mengalahkan ketentuan agama.

Pasal 7 Undang-undang Nomor 1 tahun 1974 ayat (1) menyatakan bahwa perkawinan hanya diizinkan jika pihak pria sudah mencapai umur 19 (sembilan belas) tahun dan pihak wanita sudah mencapai umur 16 (enam belas) tahun. Ketentuan batas umur ini, seperti disebutkan dalam KHI pasal 15 ayat (1),begitupun dalam berbagai hukum keluarga di negara Islam. Jika dilihat dalam al-Qur'an tidak ditemukan secara jelas tentang batas umur tersebut, tetapi dalam salah satu ayat dapat ditarik benang merahnya, yakni dalam surat an-Nisa' ayat 6:

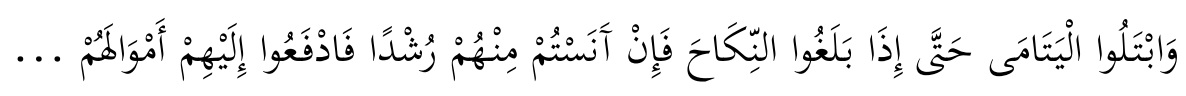

Dan ujilah anak yatim itu sampai mereka cukup umur untuk kawin. Kemudian jika menurut pendapatmu mereka telah cerdas (pandai memelihara harta), maka serabkanlah kepada mereka harta-hartanya...(QS:4:6)

Arti "cerdas" dalam ayat di atas perlu dipahami dan dinterpretasikan agar menemukan makna yang sesuai dengan konteks yang ada, maka pertimbangan sosiologis, psikologis dan dampak sosialnya sangat perlu mendapat perhatian yang serius. Dalam konteks KHI, secara lugas dapat dipahami bahwa batasan

\footnotetext{
${ }^{33}$ Ibid., h, 145-146.

${ }^{34}$ Ibid., h, 157.
} 
umur dalam perkawinan merupakan antisipatif terjadinya kawin muda yang mempunyai dampak negatif dan menjadi problem sosial, salah satunya adalah maraknya aborsi-walaupun tidak semua aborsi dilakukan akibat kawin mudayang merupakan salah satu penyebab angka kematian.

Dalam KHI dan UU Perkawinan No. 1 tahun 1974 tersebut merupakan aturan kongkrit dan relatif banyak melahirkan interpretasi dalam masyarakat. Terlepas dari hukum formal yang mengatur umur perkawinan, kawin muda merupakan fenomena yang terkait erat dengan nilai-nilai sosial, budaya, agama yang hidup dalam masyarakat.

Dalam konteks Indonesia perkawinan lebih cenderung berupa kewajiban sosial dari manifestasi kehendak bebas setiap individu. Secara umum dapat dikemukakan hipotesis; bahwa dalam masyarakat yang pola hidup hubungannya bersifat tradisional, perkawinan dipersepsikan sebagai suatu "keharusan sosial" yang merupakan bagian warisan tradisi dan dianggap sakral, sedangkan dalam masyarakat modern, perkawinan lebih dianggap sebagai "kontrak sosial", dan karenanya perkawinan lebih sering merupakan pilihan. Hal inilah cara pandang terhadap perkawinan muda yang terjadi di Indonesia. ${ }^{35}$

Alasan yang dikemukakan karena faktor ekonomi, sosial budaya atau gabungan keduanya adalah berangkat dari pemahaman bahwa mengawinkan anak perempuan sedini mungkin berarti akan meringankan beban ekonomi rumah tangga dan diasumsikan tidak lagi menjadi tanggung jawab orang tua. Adapun akibat (akses) dari kawin muda tersebut dapat dilihat dengan berdasarkan banyaknya masalah yang timbul di tengah masyarakat, antara lain:

a. Menikah dalam usia muda berarti pula hilangnya kesempatan untuk melanjutkan pendidikan. Di satu sisi tertutupnya akses untuk melanjutkan pendidikan kepada jenjang perguruan tinggi karena disibukkan dengan urusan rumah tangga, beban ekonomi domestik perempuan hamil, melahirkan dan mengurusi anak. Di sisi lain bagi yang masih di sekolah lanjutan adalah tidak diizinkannya mengikuti pelajaran jika mereka berstatus kawin atau dalam keadaan hamil.

b. Dengan usia perkawinan yang sangat dini sebagian besar berpengetahuan minim atau sama sekali tidak memiliki pengetahuan tentang hubungan seksual dan kesehatan reproduksi. Ketidaktahuan ini dalam tingkat tertentu akan menyebabkan ketakutan dalam melakukan hubungan seksual. Kemudian setelah mendapat pengalaman seksual pada umumnya mereka memandang hubungan seksual sebagai kewajiban seorang isteri untuk

\footnotetext{
${ }^{35}$ Syafiq Hasyim (ed), Menakar Harga Perempuan: Ekspolarasi Lanjut Atas Hak-hak Reproduksi Perempuan dalam Islam, (Bandung: Mizan, 1999), Cet ke-1, h. 132.
} 
melayani suami. Terkadang dampak terhadap perempuan adalah aborsi sebab secara fisik dan mental isteri belum siap untuk hamil. ${ }^{36}$

Sebaliknya pria yang kawin di bawah umur mempunyai akibat yang sama seperti halnya perempuan, terlebih lagi kesiapan secara fisik, materi atau yang lebih penting adalah secara psikologi untuk mendayung bahtera keluarga yang sangat sarat dengan kesabaran, ketulusan, dan keuletan.

Ketentuan batas umur ini, seperti disebutkan dalam KHI didasarkan kepada pertimbangan kemaslahatan keluarga dan rumah tangga perkawinan. Ini sejalan dengan prinsip yang diletakan UU Perkawinan, bahwa calon suami isteri harus telah masak jiwa raganya, agar dapat mewujudkan tujuan perkawinan secara baik tanpa berakhir pada perceraian dan mendapatkan keturunan yang baik dan sehat. Untuk itu harus dicegah adanya perkawinan atara calon suami isteri yang masih di bawah umur.

Masalah kematangan fisik dan jiwa seseorang dalam konsep Islam, tampaknya lebih ditonjolkan pada aspek yang pertama, yaitu fisik. Hal ini dapat dilihat misalnya dalam pembebanan hukum (taklif) bagi seseorang, yang dalam term teknis disebut mukallaf (dianggap mampu menanggung beban hukum). Dalam sebuah hadis, Rasulullah SAW mengatakan:

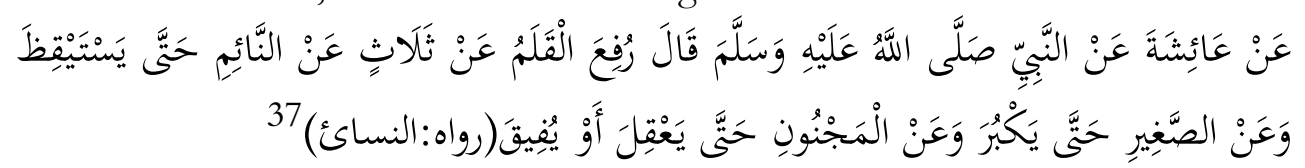

Dari 'Aisyah telah bersabda Nabi SAW: Terangkat pertanggungjawaban seseorang dari tiga hal; orang yang tidur hingga ia bangun, anak-anak. bingga ia besar (bermimpi dan mengelurkean air mani)danorang gila bingga ia sembuh atau wafa. (HR: an-Nasai)

Menurut isyarat hadis tersebut, kematangan seseorang dilihat pada gejala kematangan seksualitanya, yaitu keluar mani bagi laki-laki dan menstruasi (haid) bagi perempuan. Dari segi umur, kematangan ini, masing-masing orang berbeda saat datangnya. Namun demikian hadis ini setidaknya memberi gambaran, bahwa pada umumnya pada usia 15 tahun. Riwayat Ibn 'Umar menyebutkan:

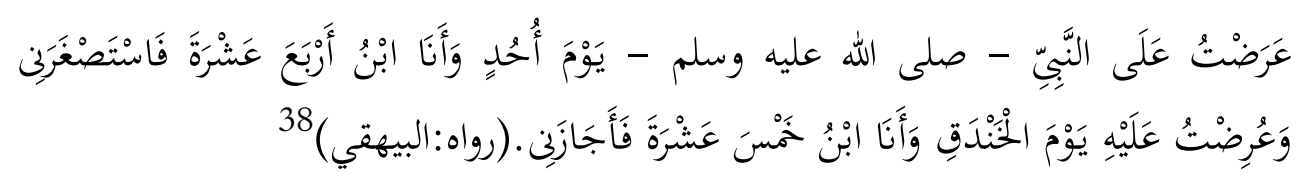

Saya telah mengajukan diri kepada Nabi SAW untuk ikut perang Ubud yang waktu itu saya baru berumur 14 tabun, beliau tidak mengizinkan aku. Dan aku mengajukan diri lagi

${ }^{36}$ Ibid., h. 143

${ }^{37}$ CD-ROOM, Op. cit., No. Hadis. 3378

${ }^{38} \mathrm{Ibid}$., No. Hadis. 262. 
kepada beliau tatkeala perang Khandaq, waktu umurku 15 tabun, dan beliau membolebkan aku (untuk mengikuti).(HR: al-Baihaqi)

Memperhatikan kedua hadis di atas, dapat diambil pemahaman bahwa batas usia 15 tahun sebagai awal masa kedewasaan bagi anak laki-laki. Karena biasanya pada usia tersebut anak laki-laki telah mengeluarkan air mani melalui mimpinya. Adapun bagi perempuan, 9 (sembilan) tahun-untuk daerah seperti Madinah-telah dianggap memiliki kedewasaan. Ini didasarkan kepada pengalaman Aisyah ketika dinikahi Rasulullah SAW:

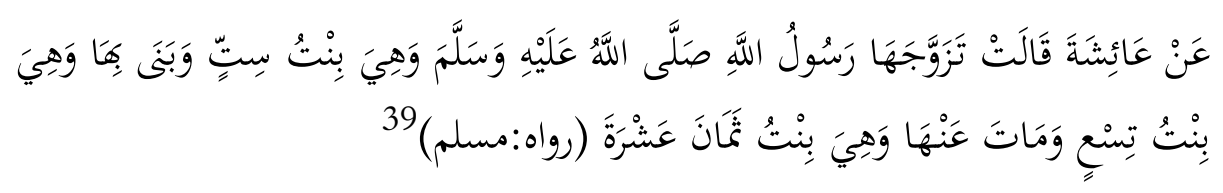

'Aisyah menyampaikan: Rasulullah menikah dengan dia (Aisyah) dalam usia enam tahun, dan beliau memboyongnya ketika ia beusia 9 (sembeilan) tabun, dan beliau wafat pada waktu dia berusia delapan belas tabun. (HR:Muslim).

Atas dasar hadis tersebut, dapat dijelaskan bahwa indikasi baligh (dewasa) seseorang itu ada tiga, yaitu sempurnanya umur 15 tahun bagi pria dan wanita, bermimpi basah (keluar mani) bagi kaki-laki dan perempuan pada usia sembilan tahun, dan haid (menstruasi) bagi wanita usia 9 (sembilan) tahun. Ini dapat dikaitkan dengan perintah Rasulullah SAW kepada kaum muslimin agar mendidik anaknya manjalankan shalat pada saat berusia tujuh tahun, dan memukulnya pada usia sepuluh tahun, apabila si anak enggan menjalankan shalat. ${ }^{40}$ Hal ini agaknya diprediksi oleh Rasulullah SAW bahwa usia di atas sembilan tahun (10) sudah baligh.

Adanya konsesi bagi calon mempelai yang kurang dari sembilan belas tahun, atau enam belas tahun bagi wanita, boleh jadi didasarkan kepada nash hadis di atas. Kendati pun kebolehan tersebut harus dilampiri izin dari pejabat untuk itu. Ini menunjukkan bahwa penanaman konsep pembaharuan hukum Islam yang memang bersifat ijtihadi, diperlukan waktu dan usaha terus-menerus. Ini dimaksudkan, pendekatan konsep maslahah mursalah dalam hukum Islam di Indonesia, memerlukan waktu agar masyarakat sebagai subyek hukum dapat menerimanya dan menjalankannya dengan suka rela tanpa ada unsur pemaksaan. Oleh karena itulah, pentingnya sosiologi hukum dalam upaya mengintrodusir pembaharuan hukum, mutlak diperlukan. ${ }^{41}$

${ }^{39}$ Ibid., No. Hadis. 2550.

${ }^{40}$ Ahmad Rofiq, Hukum Islam di Indonesia, (Jakarta: Raja Grafindo Persada, 1998), Cet ke-3,h. 82. Teks hadis tersebut lihat Sunan Abu Dawud, Hadis No. 465. Syarh as-Sunnah lilbaghawi, Hadis No. 505.

${ }^{41}$ Ibid., h. 83. 
Disamping itu pemahaman terhadap nash, utamanya yang dilakukan oleh Rasulullah SAW pada saat menikah dengan Aisyah, juga perlu dipahami sesuai dengan tuntutan situasi dan kondisi waktu itu. Ini penting, karena tuntutan kemashlahatan yang ada waktu itu dibanding dengan sekarang, jelas sudah berbeda.

Disamping itu perkawinan mempunyai hubungan dengan masalah kependudukan. Ternyata bahwa batas umur yang rendah bagi seorang wanita untuk kawin, mengakibatkan laju kelahiran lebih tinggi. Berhubung dengan itu, undang-undang ini menentukan batas umur untuk kawin baik bagi pria maupun wanita. (penjelasan umum UU Perkawinan, nomor 4 huruf d).

Pertimbangan problem kependudukan, seperti diungkapkan dalam penjelasan Undang-undang Perkawinan, turut mempengaruhi perumusan batas umur calon mempelai tersebut. Ini dimaksudkan untuk menjawab tantangan dan kebutuhan masyarakat, sejalan dengan tujuan hukum Islam itu sendiri. Sebagaiman komentar Djatmika bahwa kesemuanya itu mengandung masalah ijtibadiyah yang diselesaikan dengan ijtihad (ulama Indonesia) dengan menggunakan metode-metode istislah, istibsan, dan al-urf serta metode istidlal lainnya dengan tujuan jalb al-masalih wa dar'al-mafasid (memperoleh kebaikan dan menghindari kerusakan). ${ }^{42}$

Argumen-argumen di atas jelas bahwa kawin muda mempunyai banyak dampak yang negatif ketimbang dampak positif karena demikian kawin muda akan membawa kepada kerusakan secara fisik, psikologis dan dampak sosial terhadap pasangan suami isteri. Oleh karena itu KHI dan Undang-undang lainnya mempersempit dan mengantisipasi terjadinya kawin muda dengan memberikan batasan umur kepada calon suami isteri agar terhindar dari kebinasaan. Hal ini dilegitimasi oleh al-Qur'an surat al-Baqarah ayat 195:

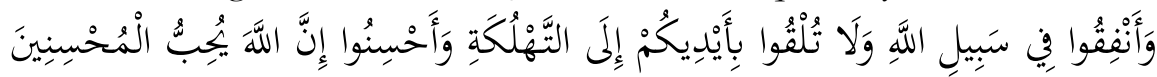

Dan belanjakanlah (harta bendamu) di jalan Allah, dan janganlah kamu menjatubkan dirimu sendiri ke dalam kebinasaan, dan berbuat baiklah, karena sesunggubnya Allah menyukai orang-orang yang berbuat baik. (QS:2:195)

Kemudian dalam kaidah fiqhiyah dijelaskan: ${ }^{43}$

1. artinya bahaya itu harus dihilangkan dalam artian mencegah kawin muda disebabkan dampak yang membahayakan kepada pasangan suami isteri yang telah diuraikan di atas.

${ }^{42}$ Ibid., h. 78.

${ }^{43}$ Imam Jalal ad-Din Abd ar-Rahman bin Abi Bakar as-Suyuthi, al-Asybah wa an-Naz̧hair, (Semarang: Maktubah wa Mathbu'ah Thoha Putera, [t.th].), h. 59. 
2. artinya tidak boleh membuat mudharat pada diri sendiri dan tidak pula mudharat pada orang lain. Contoh kawin muda akan membuat dampak negatif terhadap fisik dan psikologi laki-laki dan perempuan dan implikasinya akan terpenetrasi kepada dampak sosial masyarakat.

3. artinya menghindarkan kerusakan didahulukan atas menarik kemashlahatan. Walau pun dampak positifnya ada, namun dampak negatifnya jaul lebih besar, maka mendahulukan membuang dampak negatif lebih diutamakan dalam agama daripada mengambil dampak positifnya.

Di sini jelas sekali penerapan maqashid asy-syari'ah, karena pembatasan umur seperti yang terdapat dalam KHI dan beberapa Undang-undang adalah sebagai langkah antisipasi atau pencegahan agar implikasi negatif dapat dielaminisir dan diminimalisasi dalam rangka menjaga rusaknya eksistensi jiwa, keturunan, dan akal dalam tingkat dharuriyah dan hajizyah. Apabila hal ini diabaikan akan berdampak buruk terhadap kedua pasangan suami isteri dan anak-anak secara fisik, psikologi dan sosiologis, sehingga menimbulkan problem sosial yang pada akhirnya akan menjadi penyakit masyarakat dan bahkan dapat mengganggu stabilitas masyarakat dan negara.

Maka dari itu, pasal-pasal tersebut dibuat dan dapat ditetapkan dengan pertimbangan demografis, sosiologis, budaya dan agama karena ada kemashlahatan yang ingin dicapai. Agaknya materi Undang-undang tentang pembatasan umur ini lebih bersifat sebagai aturan tambahan karena tidak ada nash yang mengaturnya secara tegas serta aturan ini menyalahi apa yang berlaku dalam kitab-kitab fiqh mana saja, namun jika dianalisa secara lebih mendalam pembatasan umur tersebut akan dapat diterima karena baik secara langsung atau tidak, ada ulama (pendapat pribadi mujtabid) yang mengakuinya. Seperti Ibn Syubramah dan al-Buti yang berpendapat tentang tidak sah (terlarang) mengawinkan perempuan di bawah umur bahkan akad yang dilangsungkan oleh walinya dipandang batal dan tidak berpengaruh. Pendapat ini dilontarkan oleh keduanya karena tidak ada hikmah tasyri' yang ingin dicapai pada perkawinan anak yang dibawah umur bahkan mudharat yang terkandung dalam akadnya lebih banyak. Karena mereka (anak kecil belum sampai umur) tersebut merasa terpaksa untuk mengadakan perkawinan. ${ }^{44}$

Masalah penentuan umur dalam UU Perkawinan maupun dalam KHI, memang bersifat ijtihadiyah, sebagai usaha pembaharuan pemikiran figh yang lalu. Namun demikian, apabila dilacak reverensi syar'inya mempunyai landasan kuat. Misalnya isyarat Allah SWT dalam surat an-Nisa' ayat 9: [t.th.]), h. 58

${ }^{44}$ Mustafa as-Siba'i, al-Mar'ah bain al-Figh wa al-Qur'an, (Damsyik: Maktabah al-Kitab, 


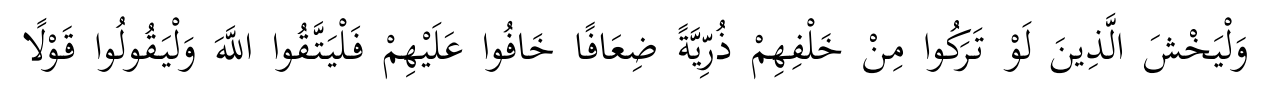

Dan hendaklab takut kepada Allah orang-orang yang seandainya meninggalkan dibelakang mereka anak-anak yang lemah, yang mereka khawatir terbadap (kesejahteraan) mereka. Oleh sebab itu hendaklah mereka bertakwa kepada Allab dan bendaklah mereka mengucapkan perkataan yang benar. (QS:4:9)

Ayat tersebut memang bersifat umum, tidak secara langsung menunjukkan bahwa perkawinan yang dilakukan oleh pasangan usia mudadibawah ketentuan yang diatur UU No.1 tahun 1974-akan menghasilkan keturunan yang dikhawatirkan kesejahteraannya. Akan tetapi berdasarkan pengamatan berbagai pihak, rendahnya usia kawin, lebih banyak menimbulkan hal-hal yang tidak sejalan dengan misi dan tujuan perkawinan, yaitu terwujudnya ketenteraman dalam rumah tangga berdasarkan kasih dan sayang. Tujuan ini tentu akan sulit terwujud, apabila masing-masing mempelai belum masak jiwa dan raganya. Kematangan dan integritas pribadi yang stabil akan sangat berpengaruh di dalam menyelesaikan setiap problerm yang muncul dalam menghadapi liku-liku dan badai rumah tangga. Banyak kasus menunjukkan bahwa banyaknya perceraian cenderung didominasi karena akibat kawin dalam usia muda.

Walaupun Undang-undang telah mengatur penentuan usia kawin, namun demikian karena sifatnya yang ijtihady, yang kebenarannya relatif, ketentuan tersebut tidak bersifat kaku. Artinya, apabila karena sesuatu dan lain hal perkawinan dari mereka yang usianya di bawah 21 tahun-atau sekurangkurangnya 19 tahun untuk pria dan 16 tahun untuk wanita-undang-undang tetap memberi jalan keluar dengan cara meminta dispensasi kepada pengadilan atau pejabat lain yang ditunjuk oleh kedua orang tua pihak pria maupun pihak wanita, sebagaimana diatur dalam pasal 7 ayat (2).

Dalam hal ini Undang-undang Perkawinan tidak konsisten. Di satu sisi, pasal 6 ayat (2) menegaskan bahwa untuk melangsungkan perkawinan seseorang yang belum mencapai umur 21 (dua puluh satu) tahun mendapat izin kedua orang tua, di sisi lain, pasal 7 ayat (1) menyebutkan perkawinan hanya diizinkan jika pihak pria sudah mencapai umur 19 (sembilan belas) tahun dan pihak wanita sudah mencapai umur 16 (enam belas) tahun. Bedanya jika kurang dari 21 tahun, yang diperlukan izin orang tua, dan jika kurang dari 19 tahun, perlu izin pengadilan. Ini dikuatkan pasal 15 ayat (2) KHI.

Pada dasarnya ketentuan tentang batas umur minimal perkawinan tidak ditentukan secara tegas dalam literatur Hukum Islam. Ketentuan ini hanya dibicarakan dalam syarat-syarat perkawinan. Namun, untuk menegakkan prinsip 
yang lima (ad-daruriyyah al-khams) serta mewujudkan maqasid asy-syari'ah maka pembatasan umur dalam perkawinan dipandang perlu dan diatur dalam undangundang yang legal agar dapat ditaati dan dilaksanakan oleh seluruh masyarakat Indonesia.

\section{Penutup}

Setelah melakukan penelitian tentang Pembatasan Usian Perkawinan maka dapat disimpulkan, bahw tinjauan Maqashid asy-Syari'ah terhadap Pembatasan Usia Perkawinan adalah, Berdasarkan analisis yang dilakukan dapat diperoleh kesimpulan bahwa pembatasan umur minimal perkawinan dalam Undang-undang Perkawinan No. 1 tahun 1974, KHI, Instrumen HAM, Hukum keluarga di dunia Islam, dan Undang-undang nomor 23 tahun 2002 tentang Perlindungan Anak dimaksudkan untuk kemaslahatan keluarga dan mampu meraih tujuan perkawinan. Pembatasan ini diperlukan mengingat banyaknya perkawinan di bawah umur yang marak terjadi di masyarakat. Sehingga kalau hal ini terjadi maka tujuan perkawinan yang diharapkan tidak akan terwujud karena yang akan terjadi adalah sebaliknya, yaitu kehancuran rumah tangga atau perceraian.

Di sini jelas sekali penerapan maqashid asy-syariah, karena pembatasan umur perkawinan adalah sebagai langkah anitisipasi atau pencegahan agar implikasi negatif dapat dielaminisir dan diminimalisasi dalam rangka menjaga rusaknya eksistensi jiwa, keturunan, dan akal dalam tingkat dharuriyah dan bajjiyah. Apabila hal ini diabaikan akan berdampak buruk terhadap kedua pasangan suami isteri dan anak-anak secara fisik, psikologi dan sosiologis, sehingga menimbulkan problem sosial yang pada akhirnya akan menjadi penyakit masyarakat dan bahkan dapat mengganggu stabilitas masyarakat dan negara.

\section{Daftar Pustaka}

BCZ Online/Kamis, 30 Oktober 2008 dalam http://www.waspada.co.id/opini/ pernikahan-dini-dan-tuntutan.html.diakses tgl 13 Januari 2010

CD-ROOM, Makhtabah Syamilah

http://www.asiamaya.com/konsultasi,diakses tanggal 23 Maret 2015

http://www.Pustaka: yayasan Peduli Anak Negeri (YPAN), diakses tanggal 5 Oktober 2015

http://www.Disalin dari "Kompilasi Hukum Islam di Indonesia", Direktorat Pembinaan Peradilan Agama Islam Ditjen Pembinaan Kelembagaan Islam Departemen Agama, 2001, diakses tanggal 25 Juni 2002 
http://www.asiamaya.com/konsultasi, diakses tanggal 25 Juni 2015

Hasyim, Syafiq .ed, Menakar Harga Perempuan: Ekspolarasi Lanjut Atas Hak-bak Reproduksi Perempuan dalam Islam, Bandung: Mizan, 1999, Cet ke-1

Ibn Ibidin, Muhammad Amin ash-Shahir bin, Hasyiyab Radd al-Mubtar, Bairut: Dar al-Fikr, t.th, Jilid 2

Al-Kasani, Ala ad-Din Abu Bakr bin Mas'ud al-Hanafi, Bada’i as-Sana'i fi Tartib ash-Shara'i,Bairut: al-Makhtabah al-'Ilmiyyah, t.th, Jilid 2

Mudzhar, M. Atho dan Khoiruddin Nasution, ed, Hukum Keluarga di Dunia Islam Modern; Studi Perbadingan dan Keberanjakan UU Modern dari Kitab-kitab Fikih,Jakarta: Ciputat Press, 2003

Mughniyah, Muhammad Jawad, Fiqh Lima Mą̧hab, penerjemah Masykur AB, Jakarta: Lentera, 1999, Cet ke-4

Rofiq, Ahmad, Hukum Islam di Indonesia, Jakarta: Raja Grafindo Persada, 1998, Cet ke-3

As-Siba'i,Mustafa, al-Mar'ah bain al-Fiqh wa al-Qur'an, Damsyik: Maktabah alKitab, t.th.

As-Suyuthi, Imam Jalal ad-Din Abd ar-Rahman bin Abi Bakar, al-Asybah wa anNaz̧bair, Semarang: Maktubah wa Mathbu'ah Thoha Putera, t.th.

Soesilo, Pramuji R, Kitab Undang-undang Hukum Perdata Burgerlijk Wetboek, Jakarta: Wippress, 2007

Trinity, KitabUndang-undang Hukum Pidana KUHP, tt.: Trinity Optima Media, 2007, Cet ke-1 